\title{
Imaging Pancreatic Beta-Cells: Update from the 4th Workshop of the National Institutes of Health, Washington DC, April 2009
}

\author{
Frederic Ris ${ }^{1}$, Lindsey Crowe ${ }^{2}$ and Thierry Berney ${ }^{1}$ \\ ${ }^{1}$ Cell Isolation and Transplantation Center, Department of Surgery, Geneva University Hospitals, 1211 Geneva, Switzerland. ${ }^{2}$ Depart- \\ ment of Radiology, Geneva University Hospitals, Geneva, Switzerland. Address correspondence to: Frederic Ris, e-mail: \\ frederic.ris@hcuge.ch
}

Manuscript submitted Oct ober 9, 2009; resubmitted D ec ember 1, 2009; accepted D ec ember 7, 2009

\section{Abstract}

There is a crucial need for developing clinically useful approaches to measure pancreatic islet mass and function. Islets represent a small percentage of the tissue located in the abdominal cavity. They remain difficult to study in vivo by non-invasive techniques due to the lack of a specific probe. Also, it is difficult to correlate imaging signals and changes in beta-cell mass. Development of new and reliable cell markers are currently in progress. A major issue for the immediate future, is to gain a better understanding of the mechanisms leading to diabetes, and to increase the possi-

\section{I maging the beta-cell mass}

r. Had (Hagedorn Research Institutes, Gentofte, Denmark) presented 2 different ap-

proaches for the discovery of novel beta-cell targets and the production of specific antibodies. In one approach, using known antigens, he developed specific antibodies after the assessment of their presence within islet cells by expression of mRNA. The other approach was to immunize cells (from mice) with islets and screen the produced antibodies for their specificity and affinity. He described new possible targets such as the Ddr1, Dner, Lrp1, Sez 612 gene products, or SIc30a8 (a gene encoding a zinc transporter). The most inter- bilities for studying islet function in vivo. Once diabetes occurs, islet transplantation is an option. However, the fate of the graft over time remains difficult to follow, due to the lack of tools to monitor rejection and inflammation before islet graft loss. The aim of this workshop was to gather the current knowledge on beta-cell imaging, including cross-linking to other field as oncology and neuroimaging.

Keywords: diabetes $\cdot$ imaging $\cdot$ beta-cell $\cdot$ antibody $\cdot$ IC2 . VMAT-2 - SIc30A8 - zinc transporter - Disp2 - exendin-3 FDYD2ya - SCA1 - M RI - PET - SPECT · sodium-potassium pump - GLP-1

esting target was the Disp2 gene product, which could allow cell sorting using a new antibody called F66. Further studies need to be performed to validate the specificity of the target and the possibility of in vivo labeling of the islets.

Maarten Brom and co-workers (Radboud University, Nijmegen, The Netherlands) presented their work on exendin-3 in rats (Table 1). Exendin3 binds to the GLP-1 receptor and after radionucleotide labeling, allowed the follow-up of islet mass in vivo by SPECT (Table 2), showing a significant correlation between exendin-3 uptake and beta-cell mass.

Rainer Leitgeb (Swiss Federal Institute of Technology, Lausanne, Switzerland) showed a 
Table 1. New beta-cell markers presented in the workshop

\begin{tabular}{|c|c|c|c|}
\hline Beta-cell probes & Species & Specificity & Imaging modality \\
\hline Exendin 3 & Rats & B eta-cell & SPECT \\
\hline SCA1 (single chain antibody) & Rats & B eta-cell & $\begin{array}{l}\text { Ex-vivo evaluation } \\
\text { by radioactivity }\end{array}$ \\
\hline FDYD2ya & Rat and human & Beta-cell & $\begin{array}{c}\text { Histological evalua- } \\
\text { tion }\end{array}$ \\
\hline $\begin{array}{l}\text { F18 AV-133 (VM AT2 imaging } \\
\text { agent used in Parkinson dis- } \\
\text { ease) }\end{array}$ & Rat and human & B eta-cell & PET \\
\hline C5.5 T cell soluble receptors & Rat & Beta-cell & PET \\
\hline IC2 autoantibody & $\begin{array}{l}\text { Mice, rat, hu- } \\
\text { man }\end{array}$ & Beta-cell & $\begin{array}{l}\text { Fluorescence opti- } \\
\text { cal imaging }\end{array}$ \\
\hline 99mTc-Glipizide & Rat & Beta-cell & SPECT \\
\hline \multicolumn{4}{|l|}{ Islet function markers } \\
\hline${ }^{18} \mathrm{~F}-\mathrm{F}$ allypride & Rat & B eta-cell & PET \\
\hline M anganese enhanced imaging & M ice, rat & B eta-cell & MRI \\
\hline \multicolumn{4}{|l|}{ Inflammation probe } \\
\hline${ }^{18} \mathrm{~F}-\mathrm{FAC}$ & Human & T-cells & PET \\
\hline${ }^{18} \mathrm{~F}$-interleukin-2 & Rat & T-cells & PET \\
\hline M NP ferumoxtran-10 & Human & T-cells & MRI \\
\hline PGC-GdDTPA-F & Rat & Vessels & M RI \\
\hline
\end{tabular}

and in vivo to show efficient PET imaging of the pancreas, with a stronger signal than in the liver $(H$. Kung, University of Pennsylvania, Philadelphia, USA), see Table 1 . The question of the specificity of VMAT-2 in the pancreas remains to be clarified, especially with the perspective of type 1 diabetes imaging. Further studies are needed to demonstrate its usefulness in a clinically relevant setting [2].

Cy5.5-labeled soluble $\mathrm{T}$ cell receptor (Anna Moore, Harvard University, Boston, USA) recognizing the insulin B chain was also shown to detect beta-cells in vitro and in vivo by near infravery attractive approach: extended focus optical coherence microscopy (Table 2) which allows islets to be imaged in vivo in small animals to a maximal depth of $500 \mu \mathrm{m}$, with a fast high resolution and label-free technique. With this technique, islet signal decrease was detected before the functional loss in streptozotocin-treated mice.

The generation of single chain antibody (SCA1) [1] by the group of Stephan Schneider (RuhrUniversity Bochum, Germany) demonstrated a high specificity for beta-cells, and showed a good correlation between beta-cell mass and signal comparing diabetic and normal animals (Table 1). The radio-labeling of this single chain antibody will lead to PET imaging to validate his usefulness in vivo.

FDYD2ya (Daisy Flamez, Université Libre de Bruxelles, Belgium) a regulating subunit of the $\mathrm{Na}^{+}-\mathrm{K}^{+}-\mathrm{ATP}$ ase was demonstrated to be only expressed in beta-cells (Table 1). Furthermore, the progressive loss of its expression in type 1 diabetes enhances the potential for non-invasive imaging before this event occurs.

${ }^{18} \mathrm{~F}$ AV-133 (VMAT-2 imaging agent, used in Parkinson disease) was successfully used in vitro red optical imaging (NIRF) (Table 1) [3].

The IC2 monoclonal antibody was also reported as a useful tool to monitor islets with a high specificity (Carl-Henrik Brogren, University of Copenhagen, Denmark) (Table 1). Other probes based on Zn transporter antibodies or GLP-1 peptide analogs [4] are under development, but specificity in imaging still needs to be determined.

\section{Imaging islet function}

Islet function is difficult to monitor. Some new strategies were presented in the workshop. ${ }^{18} \mathrm{~F}$ fallypride, a selective dopamine receptor PET tracer [5], was tested with the hypothesis that D2like receptor expression decreases according to ATP levels in the cells (Table 1). It was shown that ATP increases when insulin secretion occurs. This correlated with the decrease of the ${ }^{18} \mathrm{~F}$-fallypride signal. Therefore, decrease of the signal reflects insulin secretion by beta-cells (R. Mirbolooki, U niversity of California, Irvine, USA). This marker was also successfully used ex vivo to monitor transplanted islets in the spleen using PET. 
Another approach was the use of Manganese (Mn)-enhanced MRI to detect islet function (Tables 1 and 2). Mn labeled cells will demonstrate a change in MR signal while activated by glucose stimulation, in contrast with surrounding areas, significant changes were seen in diabetic animals with a decrease in signal due to less activated cells [6]. Those results were presented by two distinct groups (M. Haque, University of Chicago, Chicago and P. Antkowiak, University of Virginia, Charlottesville, USA) and need to be further studied in a clinical setting.

\section{Imaging islet transplantation and its outcome}

Islet transplantation is currently performed into the liver in human and at the same site in animals or under the kidney capsule. However, there is a lack of transplantation models, which could be followed to study changes over time. The group at the University of Miami (Alejandro Caicedo) presented the anterior chamber of the eye as an alternative site allowing live, noninvasive study of the graft by confocal microscopy [7]. They demonstrated a correlation between green fluorescent protein-labeled $\mathrm{T}$ cells in the graft and loss of function.
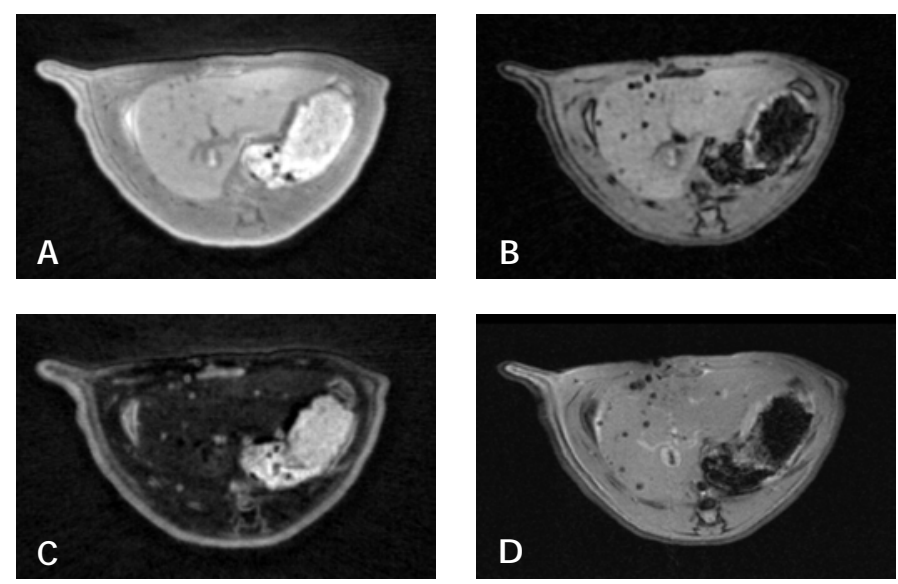

Figure 1. Ultra-short echo time MRI imaging of syngeneic ironlabeled islets. 2000 syngeneic iron-labeled (ferucarbotran) islets were transplanted into the rat liver through the portal vein. Different acquisition are performed, UTE TE $0.07 \mathrm{~ms}(\mathbf{A})$, radial TE $5.7 \mathrm{~ms}$ (B), radial difference with drawn liver border (dUTE) (C), and $2 \mathrm{D} \mathrm{GRE}$, i.e. conventional imaging (D). Subtraction of the two echoes gives difference ultra-short TE (dUTE) images with positive contrast from labeled cells, which allows quantification of the transplanted islets.
Table 2. Imaging modalities used in beta-cell studies presented during the congress

\begin{tabular}{|c|c|c|c|}
\hline & \multirow[t]{2}{*}{ In vitro } & \multicolumn{2}{|c|}{ In vivo } \\
\hline & & Animals & Human \\
\hline PET & + & + & - \\
\hline M RI & + & + & + \\
\hline CT-scanner & + & + & + \\
\hline SPECT & + & + & - \\
\hline Ultrasound & - & + & - \\
\hline $\begin{array}{l}\text { Extended focus op- } \\
\text { tical coherence mi- } \\
\text { croscopy }\end{array}$ & + & + & - \\
\hline $\begin{array}{l}\text { Near infrared opti- } \\
\text { cal imaging (NIRF) }\end{array}$ & + & + & - \\
\hline $\begin{array}{l}\text { Bioluminescence } \\
\text { imaging }\end{array}$ & + & + & - \\
\hline
\end{tabular}

The field of islet encapsulation could further develop with the aim to offer immunoprotection for the transplanted islets and the recipients. New dual strategies were reported by D. Arifin ( ohns Hopkins University, Baltimore, USA) and T. Kim (Seoul National University, South Korea). These strategies are envisaged to couple imaging and isolation with alginate microcapsules and gadolinium-gold or iron nanoparticles (ferumoxide).

Visualization of the encapsulated graft was feasible by a wide range of imaging modalities such as MRI, CTscanner, ultrasonography or X-ray (Table 2). This needs to be further correlated to islet survival as opposed to capsule survival [8]. A new 3T MRI acquisition technique was described by the group at the University of Geneva ( $F$. Ris). It allows a positive contrast to be shown on 3T MRI, and reliable and re producible quantification of transplanted islet mass. This technique will be soon applied in a pilot clinical trial (Figure 1).

\section{I maging islet inflammation}

Type 1 diabetes is an autoimmune disease resulting from the destruction of insulin producing beta-cells. The ability to visualize islet inflammation could play a key role in the understanding of the disease process and to monitor islet 
graft. The strategies to detect islet inflammation include direct visualization of islet infiltrating $T$ cells or indirect examination of the consequences of inflammation (microvasculature alterations). One of the main problems is to develop appropriate probes for in vivo imaging of the inflammatory process. ${ }^{18} \mathrm{~F}-\mathrm{FAC}\left(1-\left(2^{\prime}\right.\right.$ deoxy-2'-( $\left.{ }^{18} \mathrm{~F}\right)$-fluoroarabinofuranosyl)cytosine) was proposed as a useful tool for such a purpose (C. Radu, University of California, Los Angeles, USA). This strategy allows detection of early changes in lymphoid tissues by PET in models of systemic autoimmunity [9]. Application of the probe was mainly performed in immune cancer therapy or bone marrow transplantation. It needs further development in the field of diabetes.

${ }^{18} \mathrm{~F}$-interleukin-2 was also proposed for this purpose (A. Signore, University Sapienza, Rome, Italy) (Table 1). It is especially interesting in the context of insulitis, with a known overexpression of IL2 receptors in activated T cells. This probe could also be used in islet transplantation and follow-up [10].

An update in the field of MRI technology was reported by the group of $\mathrm{R}$. Weissleder at Harvard University. They described the use of MNP ferumoxtran-10 (Combidex), a marker of occult Iymphnodes metastases, in diabetic patients compared with control (Tables 1 and 2). They showed reproducible signal changes at 1.5T. This study was clinically relevant, even if for a small number of patients. Furthermore, the use of PGC-GdDTPA-F a gadolinium probe specific to vessels, was shown to monitor islet microvascularization changes in diabetic rat compared to normal rats (Z. Medarova, Harvard University, Boston, USA) [11].

\section{Conclusions}

This workshop has demonstrated an impressive progress in the field of islet and, more specifically, beta-cell imaging. Most advances have been obtained in basic research, either in vitro or in vivo in small animal models, and have yet to show translational potential. The need for a beta-cell specific contrast agent with high specificity and affinity, proportional to the beta-cell mass, remains a major challenge. Advances described in this workshop have set the pace for rapid progress in the field.

Acknowledgments: This work was supported in part by grant R01 Al 74225-01 from NIH/NIDDK and grant 3200B0-113899 from the Swiss National Science Foundation.

Disclosures: The authors report no conflict of interests.

\section{References}

1. Ueberberg S, Meier JJ, Waengler C, Schechinger W, Dietrich JW, Tannapfel A, Schmitz I, Schirrmacher $\mathbf{R}$, Köller M, Klein HH, Schneider S. Generation of novel single-chain antibodies by phage-display technology to direct imaging agents highly selective to pancreatic beta- or alpha cells in vivo. Diabetes 2009. 58(10):2324-2334.

2. Saudek F, Brogren $\mathbf{C H}$, Manohar S. Imaging the Betacell mass: why and how. R ev Diabet Stud 2008. 5(1):6-12.

3. Frangioni JV. In vivo near-infrared fluorescence imaging. Curr O pin Chem Bio/ 2003. 7(5):626-634.

4. Mukai E, Toyoda K, Kimura H, Kawashima H, Fujimoto $H$, Ueda $M$, Temma $T$, Hirao K, Nagakawa $\mathbf{K}$, Saji $\mathbf{H}$, Inagaki $\mathbf{N}$. GLP-1 receptor antagonist as a potential probe for pancreatic beta-cell imaging. Biochem Biophys $R$ es Commun 2009. 389(3):523-526.

5. Mukherjee J, Yang ZY, Brown T, Lew R, Wernick $M$, O uyang $X$, Yasillo $N$, Chen $C T$, Mintzer R, Cooper $\mathbf{M}$. Preliminary assessment of extrastriatal dopamine D2 receptor binding in the rodent and nonhuman primate brains using the high affinity radioligand, $18 \mathrm{~F}$-fallypride. N uCl M ed Bio/ 1999. 26(5):519-527.

6. Antkowiak PF, Tersey SA, Carter JD, Vandsburger MH, Nadler JL, Epstein FH, Mirmira RG. N oninvasive assessment of pancreatic beta-cell function in vivo with manganese-enhanced magnetic resonance imaging. $A m$ J Physiol Endocrinol M etab 2008. 296(3):E573-E578.

7. Speier S, Nyquist D, Cabrera O, Yu J, Molano RD, Pileggi A, Moede T, Köhler M, Wilbertz J, Leibiger $\mathbf{B}$, et al. N oninvasive in vivo imaging of pancreatic islet cell biology. $N$ at $M$ ed 2008. 14(5):574-578.

8. Barnett BP, Kraitchman DL, Lauzon C, Magee CA, Walczak P, Gilson WD, Arepally A, Bulte JW. R adiopaque alginate microcapsules for $\mathrm{X}$-ray visualization and immunoprotection of cellular therapeutics. $\mathrm{Mol}$ Pharm 2006. 3(5):531-538.

9. Radu CG, Shu CJ, Nair-Gill E, Shelly SM, Barrio JR, Satyamurthy N, Phelps ME, Witte ON. Molecular imaging of lymphoid organs and immune activation by positron emission tomography with a new [18F]-labeled 2'deoxycytidine analog. $N$ at $M$ ed 2008. 14(7):783-788.

10. Chianelli M, Parisella MG, Visalli N, Mather SJ, D'Alessandria C, Pozzilli P, Signore A, IMDIAB study group. Pancreatic scintigraphy with $99 \mathrm{mT}$ cinterleukin- 2 at diagnosis of type 1 diabetes and after 1 year of nicotinamide therapy. Diabetes M etab R es R ev 2008. 24(2):115-122.

11. Medarova Z, Castillo G, Dai G, Bolotin E, Bogdanov A, Moore A. N oninvasive magnetic resonance imaging of microvascular changes in type 1 diabetes. Diabetes 2007. 56(11):2677-2682. 